\title{
Production of Food Grade $\beta$-Galactosidase from Artisanal Yogurt Strains
}

\section{Canan Tari , Fatma Isık Ustok \& Sebnem Harsa}

To cite this article: Canan Tari , Fatma Isık Ustok \& Sebnem Harsa (2010) Production of Food Grade $\beta$-Galactosidase from Artisanal Yogurt Strains, Food Biotechnology, 24:1, 78-94, DOI: 10.1080/08905430903562807

To link to this article: http://dx.doi.org/10.1080/08905430903562807

$$
\text { 曲 Published online: } 08 \text { Mar } 2010 .
$$

\section{Submit your article to this journal $\sqsubset$}

Џ Article views: 115

Q View related articles $₫$

C7 Citing articles: 5 View citing articles 저 


\section{Production of Food Grade $\beta$-Galactosidase from Artisanal Yogurt Strains}

\section{Canan Tari, Fatma Isık Ustok, and Sebnem Harsa}

Department of Food Engineering, Izmir Institute of Technology, Urla, Izmir, Turkey

Superior artisanal isolates of thermophilic lactic acid bacteria producing high lactic acid and $\beta$-galactosidase were isolated from traditional Turkish yogurt samples from the Toros mountain region from a highly bio-diverse environment. A full factorial statistical design, with the factors of types of strains and medium formulations under static and agitation conditions, were applied to investigate the effects on $\beta$-galactosidase and lactic acid production. Streptococcus thermophilus 95/2 and Lactobacillus delbrueckii subsp. thermophilus 77 exhibited remarkable potential as promising starter culture candidates valuable to various applications in the dairy industry. The efficiency of cell disruption methods was investigated on the extraction of intracellular $\beta$-galactosidase enzyme. Lysozyme enzyme treatment was determined as the most effective method, which resulted in approximately 1.5 and 10 times higher enzyme activity than glass bead and homogenization treatment, respectively.

Key Words: $\beta$-galactosidase; cell disruption; lactic acid; Lactobacillus delbrueckii subsp. bulgaricus; Streptococcus thermophilus

\section{INTRODUCTION}

Thermophilic lactic acid bacteria (LAB) are widely used in the production of cheeses and fermented milk products such as yogurt (Nancip et al., 1999). Yogurt is one of the most important milk fermentation products produced by Streptococcus thermophilus and Lactobacillus delbrueckii subsp. bulgaricus (El Demerdash et al., 2006; Kristo et al., 2003). These kinds of products have become very popular staple food items with increasing consumption rates attributed to their health benefits. The healthy properties of yogurt especially come from the action of yogurt bacteria (S. thermophilus and L. bulgaricus) and their metabolites (Kristo et al., 2003).

Address correspondence to Canan Tari, Izmir Institute of Technology, Department of Food Engineering, Gulbahce Campus, 34537, Urla-Izmir, Turkey; E-mail: ctari7@ yahoo.com 
S. thermophilus ( $\mathrm{St}$ ) and L. bulgaricus $(\mathrm{Lb})$ are beneficial and economically important microorganisms that also have important functions in the process of different fermented products, including beverages (kefir, koumiss), based on bulgaricus or bifidus strains (Yokota et al., 1989).Many of these have developed in regional areas and, depending on the starter organisms used, have various flavors, textures, and components from the fermentation process, such as volatiles, carbon dioxide, or ethanol. S. thermophilus and L. bulgaricus are particularly promising microorganisms for the production of $\beta$-galactosidase enzyme, since their $\beta$-galactosidase is active at neutral $\mathrm{pH}$ and is more heat stable than the widely used Kluyveromyces lactis $\beta$-galactosidase (Greenberg and Mahoney, 1982). Moreover, hydrolysis of lactose can be achieved rapidly without growth of undesirable microorganisms at these conditions (neutral $\mathrm{pH}$ and high temperatures) (Vasiljevic and Jelen, 2001; Greenberg and Mahoney, 1982).

The enzyme $\beta$-galactosidase ( $\beta$-D- galactoside galactohydrolyse, EC.3.2.1.23) is known as a commercially important enzyme in the food and pharmaceutical industries (Cortes et al., 2005). For commercial purposes, yeasts, mold, and bacteria still remain the only sources of $\beta$-galactosidase (Vasiljevic and Jelen, 2001). Enzyme from these microorganisms with different properties can be used in different applications. For example $\beta$-galactosidase obtained from mold with $\mathrm{pH}$ optima in the range of $3-5$ and an optimum temperature range of $55-60^{\circ} \mathrm{C}$ is limited to high acid product applications and pharmaceutical preparations (Seyis and Aksoz, 2004; Nagy et al., 2001; Mahoney, 1998). On the other hand, yeast $\beta$-galactosidases characterized by their neutral $\mathrm{pH}$ optima are recognized with their higher activities (Cortes et al., 2005; Jurado et al., 2002; Martins et al., 2002). However, the major drawbacks of these enzymes are the low optimum temperatures $\left(30-37^{\circ} \mathrm{C}\right)$ and low heat stabilities, where mainly inactivation is observed at temperatures above $48^{\circ} \mathrm{C}$ (Jurado et al., 2002). Major applications of this enzyme are to hydrolyze lactose, eliminate the problems related to whey disposal, lactose crystallization in frozen concentrated desserts, and increase milk consumption of lactose-intolerant individuals (Kim and Rajogopal, 2000). In addition to these, $\beta$-galactosidase has an important role in the catalysis of transgalactosylation reaction and galacto-oligosaccharides formation (Hsu et al., 2005; Jurado et al., 2002). These factors have led researchers to survey many microorganisms with the purpose of selecting the organisms capable of producing high levels of $\beta$-galactosidase enzyme (Greenberg and Mahoney, 1982). However, the $\beta$-galactosidase from thermophilic LAB is an intracellular enzyme. Its release from microorganisms is obtained either by mechanical disruption or by chemical permeabilization of the cell membrane. The effectiveness of the various disruption methods differs for different microbial genera and strains. Generally, $\beta$-galactosidase activity can be greatly increased by rupturing cells using different cell disruption methods (Bury et al., 1999). 
With this viewpoint, traditional yogurt samples obtained from Toros mountain region of Turkey were used as the source for the isolation of artisanal LAB cultures. A total of 136 isolated strains were screened for $\beta$-galactosidase activity based on their lactose consumption and lactic acid producing characteristics according to the method described by Bulut et al. (2005) and Mora et al. (1998). Among these isolates only three Lactobacillus delbrueckii subsp. bulgaricus and three Streptococcus thermophilus strains showed high potential for lactose consumption and lactic acid production. In this study, the goal was to further optimize the fermentation conditions of these strains whose phenotypic and genotypic identification were completed and determine the strains with the highest $\beta$-galactosidase activity and lactic acid production that could be potential candidates for industrial use. It is well known that lactic acid is an economically valuable product with different applications in the pharmaceutical, chemical, textile, and food industries. The current worldwide production (including polymer uses such as formation of linear polyesters, lactoyllactic acid, and higher polylactic acids) is estimated to be around 120,000 ton per year (Datta and Henry, 2006). Existing commercial lactic acid production processes mainly use homolactic organisms including $L$. delbrueckii, L. amylaphilus, L. bulgaricus, and L. leichmanii (Datta and Henry, 2006). Therefore, in the last decade, lactic acid production has increased considerably due to the development of new applications, and the production technology is currently based on microbial fermentation, which emphasizes the demand for the discovery of new microbial sources with novel characteristics (Datta and Henry, 2006). Furthermore, these artisanal strains can also be considered as starter cultures with unique characteristics for dairy industry.

Investigation of process factors is important when considering large scale industrial applications using bioreactors. Agitation as a means of oxygen and nutrient transfer is one factor that has a great influence on the process, especially on the growth of lactic acid bacteria (Cortes et al., 2005; Beshkova et al., 2002). Therefore, the effects of strain, cultivation media, and agitation speed on lactic acid and $\beta$-galactosidase activity were investigated using full factorial statistical design for each type of strain. Also, the effectiveness of different cell disruption methods such as homogenization, glass beads, and lysozyme enzyme treatment were compared to select the most effective method for further studies.

\section{MATERIAL AND METHODS}

\section{Microorganism and Fermentation}

Streptococcus thermophilus strains coded as St 77a, St 74, and St 95/2, Lactobacillus bulgaricus strains coded as $\mathrm{Lb} \mathrm{77,} \mathrm{Lb} \mathrm{16,} \mathrm{and} \mathrm{Lb} 22 \mathrm{~b}$ isolated from traditional yogurt samples of Toros mountain region and identified by 
the Department of Food Engineering at Izmir Institute of Technology based on the phenotypic and genotypic study, were used (Erkus et al., 2006). Stock cultures of these strains were prepared $(20 \%)$ and stored at $-80^{\circ} \mathrm{C}$ in sterile cryovials. Culture propagation was performed by transferring $10 \mu \mathrm{L}$ of stock culture into $10 \mathrm{~mL}$ of sterile M17 broth for Streptococcus thermophilus and MRS for Lactobacillus bulgaricus strains and incubated at $43^{\circ} \mathrm{C}$ for $16 \mathrm{~h}$.

Fermentation was carried out in a $250 \mathrm{~mL}$ Erlenmeyer flasks containing $100 \mathrm{~mL}$ of either one of the sterilized broths $\left(113^{\circ} \mathrm{C} / 10 \mathrm{~min}\right)$ of $6 \%$ whey $(\mathrm{W})$, $6 \%$ whey $+0.2 \%$ yeast extract (WYE), $6 \%$ whey $+1.2 \%$ MRS (Difco, Detroit, Mich., USA) (WMRS) or $12 \%$ skim milk (S) for Lactobacillus bulgaricus strains (Vasiljevic and Jelen, 2001). Similarly, $2 \%$ whey $+3 \%$ corn step liquor $+2 \%$ peptone (M1), $2 \%$ whey $+3 \%$ corn step liquor $+2 \%$ peptone $+2 \%$ potassium phosphate (M2), $7 \%$ whey $+3 \%$ corn step liquor $+2 \%$ peptone (M3) or $7 \%$ whey $+3 \%$ corn step liquor $+2 \%$ peptone $+2 \%$ potassium phosphate (M4) media formulations were used for Streptococcus thermophilus strains (Greenberg and Mahoney, 1982). These were inoculated with $2.5 \mathrm{~mL}$ of the propagated culture and incubated at $43^{\circ} \mathrm{C}$ for $8 \mathrm{~h}$ with or without agitation as described in the experimental design (Tables 1 and 2).

\section{Disruption of Microbial Biomass}

Since $\beta$-galactosidase from lactic acid bacteria is an intracellular enzyme, three different disruption methods such as enzyme treatment, glass bead extraction, and homogenization were applied for each run to compare and evaluate the efficacy of these methods.

For the enzyme extraction procedure by lysozyme, $10 \mathrm{~mL}$ of fermentation broth was harvested by centrifugation at $2800 \times g$ for $15 \mathrm{~min}$ at $4^{\circ} \mathrm{C}$. The pellets then were washed with $10 \mathrm{~mL}$ of $0.05 \mathrm{M} \mathrm{Na}$ - phosphate buffer $(\mathrm{pH} 7)$ and centrifuged at $2800 \times g$ for another $15 \mathrm{~min}$. Following this step, the pellets were resuspended in $4.5 \mathrm{~mL}$ of the same buffer followed by vigorous vortexing. To this solution, $100 \mathrm{mg}$ lysozyme (Sigma L 6876) was added and incubated at $37^{\circ} \mathrm{C}$ for $15 \mathrm{~min}$. This step was later followed by the addition of $0.5 \mathrm{~mL}$ of $4 \mathrm{M}$ $\mathrm{NaCl}$ solution and further incubation of $50 \mathrm{~min}$. After this period the suspension was centrifuged at $2800 \times g$ for $15 \mathrm{~min}$ and supernatant was used for the enzyme assay.

For the glass beads procedure, $10 \mathrm{~mL}$ of fermentation broth was harvested by centrifugation and washed with $0.05 \mathrm{M} \mathrm{Na}$ - phosphate buffer $(\mathrm{pH} 7)$ as described above. Following this step, the pellets were resuspended in $5 \mathrm{~mL}$ of the same buffer followed by vigorous vortexing. To this solution, $5 \mathrm{~g}$ glass beads (Marienfield glass beads, $1 \mathrm{~mm}$ in diameter) were added and vortexed at $2700 \mathrm{rpm}$ using 8 operating cycles ( 1 operating cycle $=1$ min operation +30 sec cooling on ice). At the end of eighth cycle, the solution was centrifuged at $2800 \times g$ for $15 \mathrm{~min}$ at $4^{\circ} \mathrm{C}$, and the supernatant was used for the enzyme assay. 
Table 1: Full factorial design and experimental results of lactic acid and $\beta$-galactosidase activity extracted by using lysozyme, glass beads and homogenizer for Lactobacillus bulgaricus strains.

\begin{tabular}{|c|c|c|c|c|c|c|c|}
\hline Combination & Strain & Media & Agitation & $\begin{array}{l}\text { Lactic Acid }^{\mathrm{a}} \\
\left(\mathrm{g} \mathrm{L}^{-1}\right)\end{array}$ & $\begin{array}{l}\text { Activity } \\
\left(U \mathrm{~mL}^{-1}\right) \\
\text { Lysozyme }\end{array}$ & $\begin{array}{c}\text { Activityc } \\
\left(\mathrm{U} \mathrm{mL}^{-1}\right) \\
\text { Glass } \\
\text { beads }\end{array}$ & $\begin{array}{c}\text { Activityd }^{\mathrm{d}} \\
\left(\mathrm{U} \mathrm{mL}^{-1}\right) \\
\text { Homogenizer }\end{array}$ \\
\hline 1 & Lb22b & WYE & 0 & 3.79 & 0.025 & 0.0212 & 0.0024 \\
\hline 2 & Lb77 & WYE & 0 & 5.23 & 0.024 & 0.0204 & 0.0026 \\
\hline 3 & Lb16 & WYE & 150 & 3.31 & 0.019 & 0.0194 & 0.0018 \\
\hline 4 & Lb22b & & 0 & 8.72 & 0.128 & 0.1022 & 0.0134 \\
\hline 5 & Lb22b & S & 150 & 3.01 & 0.087 & 0.0762 & 0.0098 \\
\hline 6 & Lb22b & W & 0 & 4.62 & 0.029 & 0.0252 & 0.0030 \\
\hline 7 & Lb77 & WMRS & 150 & 3.36 & 0.018 & 0.0148 & 0.0016 \\
\hline 8 & Lbl6 & & 150 & 2.44 & 0.045 & 0.0318 & 0,0044 \\
\hline 9 & Lb22b & W & 150 & 2.83 & 0.028 & 0.0262 & 0.0022 \\
\hline 10 & Lblo & W & 0 & 4.80 & 0.027 & 0.0240 & 0.0030 \\
\hline 11 & Lb77 & W & 150 & 2.50 & 0.028 & 0.0206 & 0.0022 \\
\hline 12 & Lb77 & W & 0 & 4.60 & 0.042 & 0.0366 & 0.0042 \\
\hline $1 \overline{3}$ & Lb16 & WYE & 0 & 4.90 & 0.022 & 0.0216 & 0.0022 \\
\hline 14 & Lb16 & WMRS & 150 & 3.59 & 0.013 & 0.0128 & 0.0012 \\
\hline 15 & Lb16 & & 150 & 4.02 & 0.109 & 0.1378 & 0.0098 \\
\hline 16 & Lb22b & WMRS & 0 & 4.30 & 0.019 & 0.0184 & 0.0018 \\
\hline 17 & Lb16 & WMRS & 0 & 5.15 & 0.017 & 0.0152 & 0.0018 \\
\hline 18 & Lb77 & $\mathrm{S}$ & 150 & 2.15 & 0.030 & 0.0240 & 0.0028 \\
\hline 19 & Lb22b & WYE & 150 & 2.02 & 0.022 & 0.0240 & 0.0024 \\
\hline 20 & Lb77 & & 0 & 3.71 & 0.240 & 0.1860 & 0.0240 \\
\hline 21 & Lb77 & WMRS & 0 & 3.70 & 0.104 & 0.0090 & 0.0010 \\
\hline 22 & Lblo & & 0 & 4.49 & 0.046 & 0.0362 & 0.0048 \\
\hline 23 & Lb22b & WMRS & 150 & 2.85 & 0.011 & 0.0132 & 0.0012 \\
\hline 24 & Lb77 & WYE & 150 & 2.93 & 0.024 & 0.0206 & 0.0260 \\
\hline
\end{tabular}

$a, b, c, d$, Mean standard deviations for lactic acid, lysozyme, glass bead and homogenization treatments were determined as $0.15 \mathrm{~g} \mathrm{~L}^{-1}, 0.002 \mathrm{U} \mathrm{mL}^{-1}, 0.003 \mathrm{U} \mathrm{mL}$ and $0.0004 \mathrm{U} \mathrm{mL}^{-1}$, respectively. Mean values and standard deviations were calculated based on two replications.

W: $6 \%$ whey, WYE: $6 \%$ whey supplemented with $0.2 \%$ yeast extract, WMRS: $6 \%$ whey supplemented with $1.2 \%$ MRS, S: $12 \%$ skim milk.

For the extraction using the homogenizer, $30 \mathrm{~mL}$ of fermentation broth was harvested by centrifugation at $2800 \times g$ for $15 \mathrm{~min}$ at $4^{\circ} \mathrm{C}$. Then the pellets were washed with $30 \mathrm{~mL}$ of $0.05 \mathrm{M} \mathrm{Na-phosphate} \mathrm{buffer}(\mathrm{pH} 7)$ and centrifuged at $2800 \times g$ for another $15 \mathrm{~min}$, and the pellets were resuspended in $15 \mathrm{~mL}$ buffer. The cell disruption was performed on the pellet suspension (15 mL) using the homogenizer (Yellow Line DI 18 Basic Homogenizer) by applying 4 operating cycles ( 1 operating cycle $=45 \mathrm{sec}$ operating $+30 \mathrm{sec}$ pause $)$ at $14000 \mathrm{rpm}$. Following this procedure the solution was centrifuged at $2800 \times g$ for $15 \mathrm{~min}$ at $4^{\circ} \mathrm{C}$; the supernatant was used for the enzyme assay.

\section{Enzyme and Protein Assay}

For the determination of $\beta$-galactosidase activity, the procedure described in Food Chemicals Codex-National Academy of Sciences (1996) was used. The 
Table 2: Full factorial design and experimental results of lactic acid and $\beta$-galactosidase activity extracted by using lysozyme, glass beads and homogenizer for Streptococcus thermophilus strains

\begin{tabular}{|c|c|c|c|c|c|c|c|}
\hline Combination & Strain & Media & Agitation & $\begin{array}{l}\text { Lactic } \\
\text { Acida } \\
\left(g^{-1}\right)\end{array}$ & $\begin{array}{l}\text { Activity } \\
\left(\mathrm{U} \mathrm{mL}^{-1}\right) \\
\text { Lysozyme }\end{array}$ & $\begin{array}{c}\text { Activity }^{c} \\
\left(\mathrm{U} \mathrm{mL}^{-1}\right) \\
\text { Glass } \\
\text { beads }\end{array}$ & $\begin{array}{c}\text { Activity } \\
\left(U \mathrm{~mL}^{-1}\right) \\
\text { Homogenizer }\end{array}$ \\
\hline $\begin{array}{l}1 \\
2 \\
3 \\
4 \\
5 \\
6 \\
7 \\
8 \\
9 \\
10 \\
11 \\
12 \\
13 \\
14 \\
15 \\
16 \\
17 \\
18 \\
19 \\
20 \\
21 \\
22 \\
23 \\
24\end{array}$ & 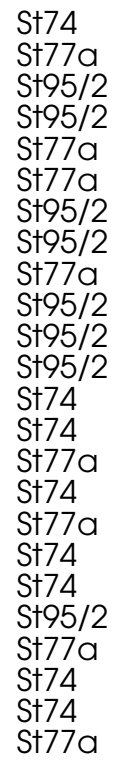 & $\begin{array}{l}\text { M1 } \\
\text { M1 } \\
\text { M4 } \\
\text { M1 } \\
\text { M1 } \\
\text { M4 } \\
\text { M3 } \\
\text { M2 } \\
\text { M3 } \\
\text { M1 } \\
\text { M3 } \\
\text { M2 } \\
\text { M3 } \\
\text { M3 } \\
\text { M2 } \\
\text { M1 } \\
\text { M4 } \\
\text { M2 } \\
\text { M4 } \\
\text { M4 } \\
\text { M3 } \\
\text { M4 } \\
\text { M2 } \\
\text { M2 }\end{array}$ & $\begin{array}{r}0 \\
150 \\
150 \\
150 \\
0 \\
0 \\
0 \\
0 \\
0 \\
0 \\
150 \\
150 \\
0 \\
150 \\
150 \\
150 \\
150 \\
0 \\
0 \\
0 \\
150 \\
150 \\
150 \\
0\end{array}$ & $\begin{array}{r}7.69 \\
6.08 \\
9.04 \\
6.98 \\
7.19 \\
8.15 \\
4.85 \\
14.44 \\
5.68 \\
5.70 \\
5.52 \\
13.09 \\
6.77 \\
5.24 \\
7.65 \\
4.14 \\
5.91 \\
10.86 \\
11.73 \\
6.51 \\
4.03 \\
7.09 \\
8.41 \\
9.81\end{array}$ & $\begin{array}{l}0.0539 \\
0.6177 \\
0.0192 \\
0.0612 \\
0.1042 \\
0.0321 \\
0.0485 \\
0.7390 \\
0.0973 \\
0.1247 \\
0.0290 \\
0.7370 \\
0.0528 \\
0.0272 \\
0.1376 \\
0.0411 \\
0.0452 \\
0.2819 \\
0.2978 \\
0.0717 \\
0.0667 \\
0.0350 \\
0.0251 \\
0.7537\end{array}$ & $\begin{array}{l}0.0370 \\
0.4380 \\
0.0156 \\
0.0298 \\
0.0603 \\
0.0259 \\
0.0376 \\
0.5582 \\
0.0705 \\
0.1026 \\
0.0247 \\
0.5792 \\
0.0381 \\
0.0202 \\
0.0972 \\
0.0305 \\
0.0345 \\
0.1689 \\
0.1844 \\
0.0458 \\
0.0418 \\
0.0240 \\
0.0208 \\
0.5471\end{array}$ & $\begin{array}{l}0.0043 \\
0.0543 \\
0.0031 \\
0.0058 \\
0.0095 \\
0.0035 \\
0.0050 \\
0.0749 \\
0.0101 \\
0.0131 \\
0.0028 \\
0.0727 \\
0.0053 \\
0.0033 \\
0.0142 \\
0.0041 \\
0.0045 \\
0.0275 \\
0.0308 \\
0.0092 \\
0.0071 \\
0.0035 \\
0.0026 \\
0.0766\end{array}$ \\
\hline
\end{tabular}

a,b,c,d, Mean standard deviations for lactic acid, lysozyme, glass bead and homogenization treatments were determined as $0.18 \mathrm{~g} \mathrm{~L}^{-1}, 0.005 \mathrm{U} \mathrm{mL}^{-1}, 0.006 \mathrm{U} \mathrm{mL}^{-1}$ and $0.001 \mathrm{U} \mathrm{mL}^{-1}$, respectively. Mean values and standard deviations were calculated based on two replications.

M1: $2 \%$ whey $+3 \%$ corn step liquor $+2 \%$ peptone, $M 2: 2 \%$ whey $+3 \%$ corn step liquor $+2 \%$ peptone $+2 \%$ potassium phosphate, M3: $7 \%$ whey $+3 \%$ corn step liquor $+2 \%$ peptone, M4: $7 \%$ whey $+3 \%$ corn step liquor $+2 \%$ peptone $+2 \%$ potassium phosphate.

chromogenic substrate o-nitrophenol- $\beta$-D-galactopyranoside (ONPG) $(8.3 \times$ $10^{-3} \mathrm{M}$ ) dissolved in $0.05 \mathrm{M}$ sodium phosphate buffer ( $\mathrm{pH} 7.0$ ) was used. The amount of enzyme and substrate used were $0.5 \mathrm{~mL}$ and $2 \mathrm{~mL}$, respectively. At time zero, $0.5 \mathrm{~mL}$ of enzyme solution was added to the pre-heated ONPG solution and incubated for $15 \mathrm{~min}$. After this time, the assay was stopped by adding $0.5 \mathrm{~mL} 10 \%$ sodium carbonate, and the absorbance was recorded at $420 \mathrm{~nm}$. One unit was defined as the quantity of enzyme that would liberate $1 \mathrm{mM}$ of o-nitrophenol from ONPG per minute under the assay conditions. The method of Bradford with BSA as a standard was used to measure protein content (Roe, 2001). 


\section{Lactic Acid Quantification}

Lactic acid determination was performed by using Perkin Elmer HPLC system (Perkin Elmer, Boston, Mass., USA) including a pump (PE Series 200), refractive index detector (PE Series 200), and Interface (PE Series 900). Aminex HPX-87H ion exclusion column $(300 \times 7.8 \mathrm{~mm})($ Bio-Rad Laboratories, Hercules, Calif., USA) was used for separation. The temperature of the column oven was $45^{\circ} \mathrm{C}$ during the analysis (Metatherm, Lake Forest, Calif., USA). Throughout the analysis $5 \mathrm{mM} \mathrm{H}_{2} \mathrm{SO}_{4}$ as mobile phase at a flow rate of $0.6 \mathrm{~mL}$ $\min ^{-1}$ was applied. Data acquisition and peak processing were done by Total Chrom Workstation Ver.6.2.1 software (Perkin Elmer). Peak identification was based on retention times, and peak quantification was carried out by the external standard method.

\section{Experimental Design and Statistical Analysis}

The effects of strain, media and agitation speed were investigated on the responses of lactic acid and $\beta$-galactosidase activity using full factorial statistical design for each type of strain separately. The level of the factors were such as three type of strains (St 77a, St 74, St 95/2 and Lb 77, Lb 16, Lb 22b), four types of media formulation mentioned (mentioned in fermentation section), and two types of agitation speed (static and $150 \mathrm{rpm}$ ). Analysis of data and generation of graphics were done by the software Design Expert 7.0.0 Trial Version, Stat-Ease Inc. (Minneapolis, Minn., USA). The analysis of variance (ANOVA) tables were generated and the effect of factors and interaction terms were determined. The significances of all terms were judged statistically according to their p-values.

\section{RESULTS AND DISCUSSION}

\section{Determination of the Specific Growth Rates and Optimum Incubation Time}

As mentioned previously, $\beta$-galactosidase is an intracellular enzyme that requires cell disruption or cell permeabilization for its release. The kinetics of cell disruption or permeabilization, however, is closely related to the physiological state of the cells and growth conditions applied. For example, as it is reported by many investigators, cells harvested during the log phase of growth are more easily disrupted than those harvested during stationary phase (Beccerra et al., 2001). This is partly explained by the lower specific growth rates observed during stationary phase which is due to the redirection of the energy sources towards synthesis and strengthening of the cell wall structure rather than cell reproduction (Altiok et al., 2006; Beccerra et al., 2001). 
To determine the specific growth rates and the right incubation time for maximum yield of $\beta$-galactosidase production and easy cell disruption, strains (Lb 16, Lb 22b, Lb77, St 74, St 77a and St 95/2) were subjected to fermentation in $100 \mathrm{~mL}$ of M17 broth and MRS broth for Streptococcus thermophilus and Lactobacillus bulgaricus strains, respectively. The fermentations were carried out with an inoculation amount of $2.5 \%$ under static conditions at $43^{\circ} \mathrm{C}$. Samples were taken and analyzed for enzyme activity and cell counts. The $\beta$-galactosidase enzyme was extracted using lysozyme extraction method during this study. The specific growth rates were determined from the growth curves as $0.635 \mathrm{~h}^{-1}, 0.732 \mathrm{~h}^{-1}$ and $0.893 \mathrm{~h}^{-1}$ for St 74, St 95/2 and St 77a, respectively. Similarly, specific growth rates of Lactobacillus bulgaricus strains were determined from the growth curves as $0.43 \mathrm{~h}^{-1}, 0.54 \mathrm{~h}^{-1}$ and $0.56 \mathrm{~h}^{-1}$ for $\mathrm{Lb} 77$, $\mathrm{Lb} 22 \mathrm{~b}$ and $\mathrm{Lb} 16$, respectively. These were higher when compared to a study performed by El Demerdash et al. (2006) using Streptococcus thermophilus.

The highest enzyme production was achieved at $8 \mathrm{~h}$ for strains $\mathrm{Lb} 77, \mathrm{Lb} 22 \mathrm{~b}$, St 74, St 77a and $6 \mathrm{~h}$ for Lb 16, St 95/2, as seen from Fig. 1. Based on these findings, incubation time of $8 \mathrm{~h}$ was kept constant in future studies (difference in maximum enzyme activities between 6 and $8 \mathrm{~h}$ was not significant for strain St 95/2 and Lb 16).

Even though the specific growth rates were slightly different among the strains, the maximum $\beta$-galactosidase productivities were in close approximation such as $0.0189,0.028$, and $0.0162 \mathrm{U} \mathrm{mL}^{-1} \mathrm{~h}^{-1}$ for strains St 74, St 95/2, and St77a, respectively. The productivities for $\mathrm{Lb} 77, \mathrm{Lb} 22 \mathrm{~b}$, and $\mathrm{Lb} 16$ were $0.0293,0.0116$, and $0.0132 \mathrm{U} \mathrm{mL}^{-1} \mathrm{~h}^{-1}$, respectively. There was an inverse

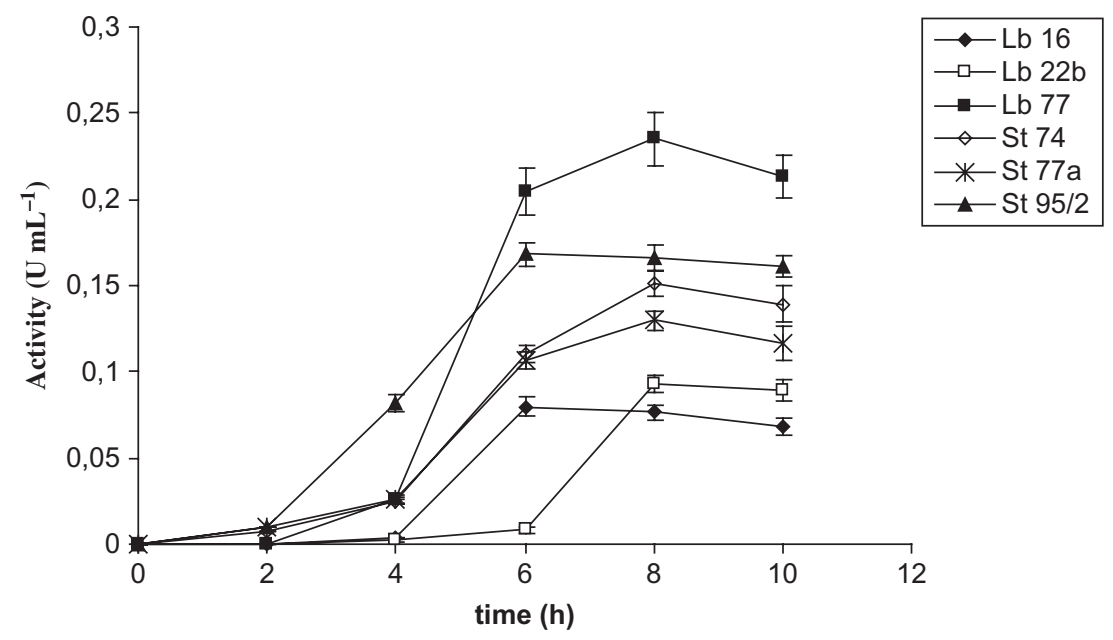

Figure 1: $\beta$-Galactosidase profiles of Lactobacillus bulgaricus and Streptococcus thermophilus in MRS and M17 growth medium, respectively at $43^{\circ} \mathrm{C}$ under static conditions. Each data point represents the average of three replicates. 
relationship between the growth rates and the enzyme activities, especially for Lactobacillus strains. This observation confirms the known phenomena that lactase production is both growth and nongrowth associated process, which has been stated by many previous studies (Beshkova et al., 2002).

\section{Effects of Strain, Media, and Agitation Speed on Lactic Acid Production}

According to ANOVA (table not shown), all the linear and interaction terms were significant $(p<0.0001)$ for lactic acid formation. The highest lactic acid production was obtained using $\mathrm{Lb} 22 \mathrm{~b}$ strain in skim milk media under static conditions. Namely, it produced 1.88, 2.028, and 2.30 times more lactic acid compared to the cultivation in whey, whey supplemented with MRS, and whey supplemented with yeast extract, respectively (Table 1, Combinations 6 and 4; 1 and $4 ; 16$ and 4 ). However, increasing the agitation speed to $150 \mathrm{rpm}$ reduced the lactic acid production in all Lactobacillus bulgaricus strains (Table 1).

Although M2 media formulation promoted lactic acid production for almost all three strains under both static and agitation conditions, M4 promoted $40 \%$ more lactic acid for St 74 specifically under static conditions (Table 2, combinations 19 and 22). Increasing the agitation speed to $150 \mathrm{rpm}$ reduced the lactic acid formation by $9.3 \%, 22 \%$, and $22.5 \%$ for St $95 / 2$, St 77a, and St 74, respectively, in M2 medium (Table 2, combinations 8, 12, 15, 18, 23, 24). As a result, it can be deduced that strain St 95/2 in M2 medium with preference for static environment is the potential strain for maximum lactic acid production. In a study performed by Nancip et al. (1999) on the production of lactic acid by Streptococcus thermophilus, they determined a maximum lactic acid amount of $2.36 \mathrm{mg} \mathrm{mL}-1$ using date products, whereas our results obtained in this study were higher than those. Similarly, comparing the current results with a study conducted by Vasiljevic and Jelen (2001) in the investigation of the production of $\beta$-galactosidase for lactose hydrolysis in milk and dairy products using lactic acid bacteria, our results were almost 10-15 times higher with respect to lactic acid production. Similarly, our findings were in good correlation with a study conducted by Büyükkileci and Harsa (2004) and Altıok et al. (2006) who investigated the lactic acid formation characteristics of Lactobacillus caseii (NRRL B 441). Clearly, these findings demonstrate that the strain St 95/2 can be considered as a potential candidate for lactic acid production.

\section{Effects of Strain, Media, and Agitation Speed on $\beta$-galactosidase Production}

According to ANOVA results (table not shown) for Lactobacillus bulgaricus and Streptococcus thermophilus strains, all factors and interaction effects were found significant $(\mathrm{p}<0.05)$ on $\beta$-galactosidase production for all extraction 
methods applied. Considering the interactive effect of strain and media formulation, skim milk was found to be the best media formulation enhancing enzyme production in all three Lactobacillus bulgaricus strains at both agitation speeds and with all cell disruption methods applied. The highest enzyme activity was observed for strain Lb 77 approximately 2 times more than Lb $22 \mathrm{~b}$ and 5 times more than Lb 16 at static environment (Table 1, combinations 4, 20, and 22). However, this was reversed under $150 \mathrm{rpm}$, where Lb 77 was the strain with the lowest activity. This difference was explained by the sole effect of agitation which was indirectly related to the oxygen supply. From these results, it can be concluded that $\mathrm{Lb} 77$ is the strain with the preference for anaerobic condition whereas Lb 16 is on the contrary a strain with aerobic preference. Strain Lb $22 \mathrm{~b}$ seems to exhibit an intermediate tolerance to oxygen. Of course the effect of agitation can not be only related to the effect of oxygen supply. It is also related to the nutrient mass transfer, which is also enhanced with agitation.

Considering Streptococcus strains, M2 medium was the best media formulation enhancing enzyme production in all three strains at static conditions (Table 2 combinations 8, 18, and 24). Under these conditions strains St 95/2 and St 77a exhibited high enzyme activity, whereas strain St 74 exhibited the lowest activity regardless of the type of extraction method applied. This observation could be partly related to the presence of potassium phosphate that could have an influence on the enzyme synthesis for the two strains (St 95/2 and St 77a) but not being effective in strain St 74 . Its effect could be attributed to the buffering capacity that plays an important role especially in LAB cultures. Besides, this finding emphasizes the different characteristics of the three strains used.

In the investigation of the interactive effect of agitation speed and media formulations on enzyme activity, it was observed that strain St 95/2 was not affected by the agitation in medium M2 (Table 2, combinations 8 and 12). This is thought to be an important finding from industrial point of view, since it gives flexibility to the manufacturer when used in large scale processes. Agitation plays a vital role in shake flask systems since it becomes the means of oxygen and nutrient supply to cells. As is observed, the strains are affected differently by the degree of agitation. From here it can be concluded that strain St 74 is more fastidious and with the preference for anaerobic conditions compared to the strains St $77 \mathrm{a}$ and St $95 / 2$.

It is seen that medium M3 and medium M4 resulted in lowest enzyme activity. This was partly attributed to the media composition that some of its ingredients might have been detrimental to enzyme synthesis. It is well known that lactic acid bacteria are fastidious microorganisms with complex growth requirements for micro and macro nutrients, required for cellular growth and maintenance (Gaudreau et al., 2005; Ghaly et al., 2004; Vasiljevic 
and Jelen, 2001). In order to encourage the growth and product formation in lactic acid bacteria in whey, complex nutrients such as, malt sprouts, corn step liquor, yeast extract, meat extract or hydrolyzed whey proteins were recommended in many studies (Aeschlimann and von Stockor, 1989; Bury et al., 1999; Ghaly et al., 2004). The highest $\beta$-galactosidase activity level obtained in this study using St 95/2 and St 77a strains especially using medium M2 under static conditions was comparable to many studies in the literature (Greenberg and Mahoney, 1982; Somkuti et al., 1996; Somkuti et al., 1998) and very promising for many industrial applications with respect to its low cost media composition. Strain St 95/2, besides having the high potential as $\beta$-galactosidase producer was also determined to be a high lactic acid producer and as starter culture to be used in many dairy applications.

\section{Comparison of Cell Disruption Methods}

As mentioned previously, $\beta$-galactosidase enzyme in Lactobacillus bulgaricus and Streptococcus thermophilus cultures is a cytoplasmic enzyme whose expression of activity is achieved through the perturbation of cell integrity by means of either sonication, mechanical, enzymatic, or chemical treatments (Somkuti et al., 1998). The disruption of cells is the first and important stage in the isolation and preparation of intracellular products such as $\beta$-galactosidase. The effectiveness of various treatment methods differs for different microbial genera and strains (Geciova et al., 2002). Therefore, in this study, three different $\beta$-galactosidase extraction methods including lysozyme, glass beads, and homogenization were compared and the most effective method determined. Lysozyme, used in enzymatic lyses, is mainly based on the digestion of the peptidoglycan layer of the bacterial cell wall.

In this study, the highest total and specific enzyme activities were achieved when enzyme extraction was performed using lysozyme enzyme treatment for both Lactobacillus bulgaricus and Streptococcus thermophilus strains. (Figs. 2a,b, Figs. 3a,b). This treatment resulted in 9.53, 10.03, and 9.77 times more $\beta$-galactosidase activity than homogenizer and $1.25,1.3$, and 1.29 times more activity than glass bead extraction for $\mathrm{Lb} 22 \mathrm{~b}, \mathrm{Lb} 77$, and $\mathrm{Lb}$ 16 , respectively. In addition, the ratio of lysozyme enzyme treatment over glass bead was determined as $1.32,1.67$, and 1.38 (considering total enzyme activities) for St 95/2, St 74, and St 77a, respectively. Under the same conditions enzyme extraction by glass beads resulted into higher enzyme activity compared to the extraction done by using the homogenizer. The lowest activity was obtained in the extraction method using the homogenizer, almost 10 times less than lysozyme treatment. Although ice cooling was provided during the homogenization process, it was thought that this was not sufficient to decrease the heat generation accounted due to hydraulic and mechanic shear. Therefore, this might have been responsible for the low enzyme activity. 

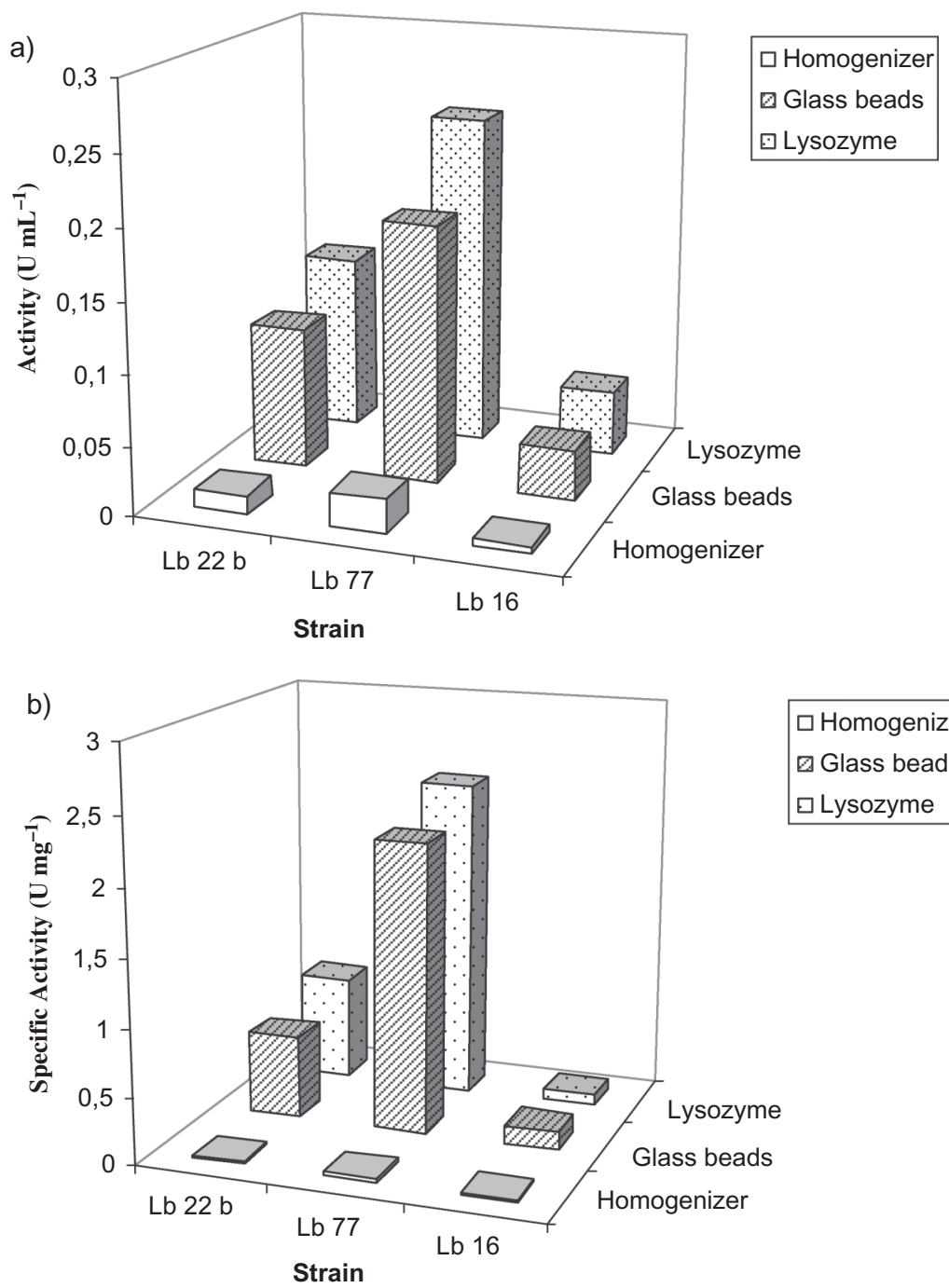

Figure 2: Comparison of the extraction methods for Lactobacillus bulgaricus strains: (Skim milk was used as cultivation media under static conditions at $43^{\circ} \mathrm{C}$ incubated for 8 h) a) Activity $\left(\mathrm{U} \mathrm{mL}^{-1}\right)$, b) Specific activity $\left(\mathrm{U} \mathrm{mg}^{-1}\right)$. Each data represents the average of two replicates.

The overall comparison of specific enzyme activities (U/mg protein) using the above mentioned methods is presented in Figs. $2 \mathrm{~b}$ and $3 \mathrm{~b}$. In fact specific enzyme activity is an indirect indication of the purity of the crude enzyme and it is desired to be as high as possible. From these figures it is observed that similar to the enzyme activity data; highest specific enzyme activity (based on the crude enzyme) was obtained with lysozyme enzyme treatment. Similarly, this treatment resulted into 51, 80, and 12 times more specific $\beta$-galactosidase 

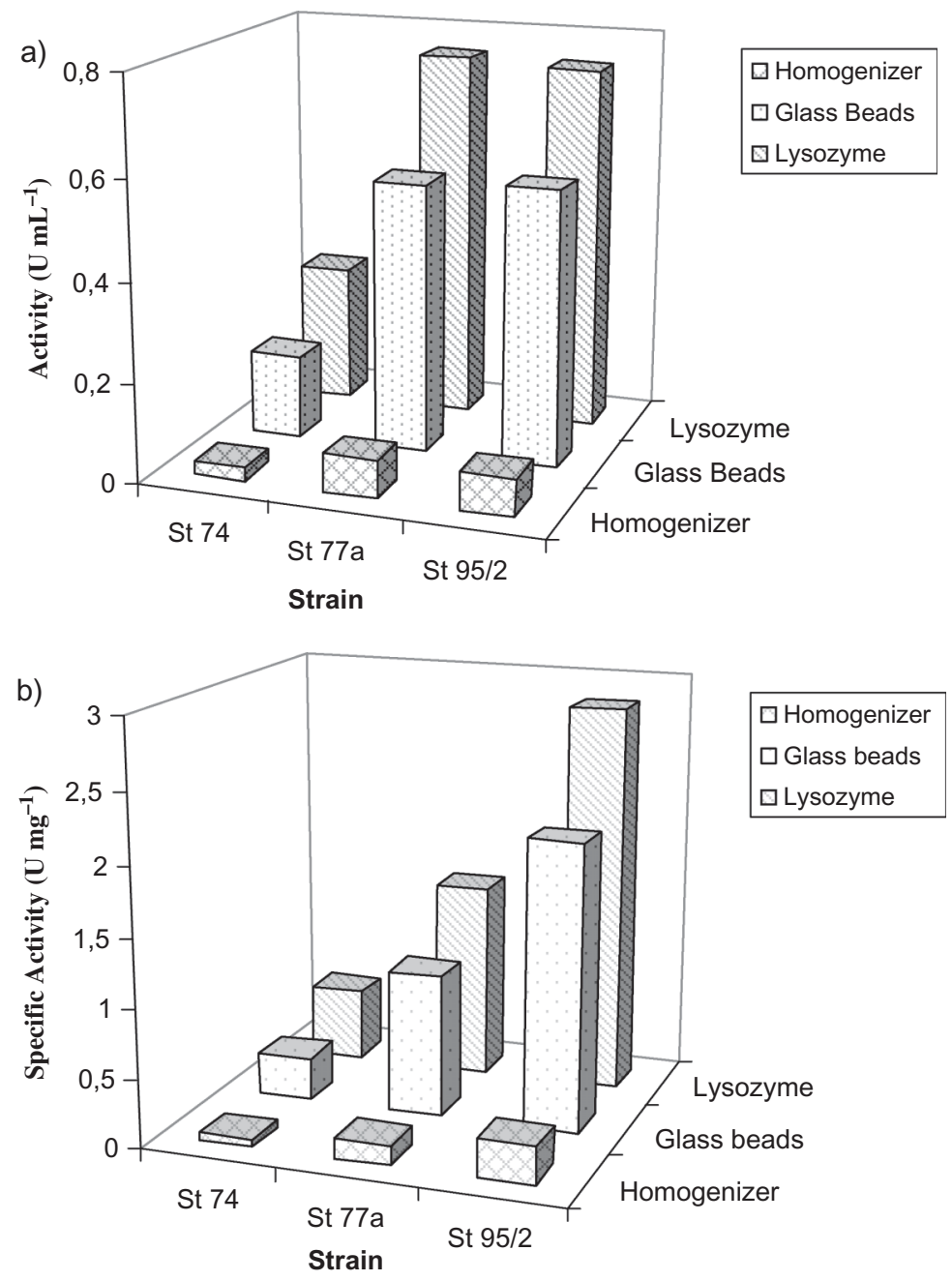

Figure 3: Comparison of the extraction methods for Streptococcus thermophilus strains: (Media 2 was used as cultivation media under static conditions at $43^{\circ} \mathrm{C}$ incubated for $8 \mathrm{~h}$ ) a) activity $\left(\mathrm{U} \mathrm{mL}^{-1}\right)$, b) specific activity $\left(\mathrm{U} \mathrm{mg}^{-1}\right)$. Each data represents the average of two replicates.

activity than the homogenizer and $1.3,1.1$, and 0.6 times more specific $\beta$ galactosidase activity than glass bead extraction for $\mathrm{Lb} 22 \mathrm{~b}, \mathrm{Lb} 77$, and $\mathrm{Lb} 16$, respectively. These results clearly show that the lysozyme enzyme treatment is more effective in extracting $\beta$-galactosidase with higher activities and less side reactions or impurities compared to the other two methods. This is more prominent in strain Lb 77 followed by strains Lb 22b and Lb 16.

Considering specific activities, similar results where lysozyme enzyme treatment is more effective in extracting $\beta$-galactosidase with higher activity 
and less side reactions compared to the other two methods were observed for Streptococcus thermophilus strains (Fig. 3b). In the comparison of the effectiveness of each method on specific activities, it was determined that lysozyme treatment was 5.39 and 1.98 times more effective on St 95/2 than on St 77a and St 74, respectively (Fig. 3b). Similarly, these values were 6.62 and 2.01 times considering glass bead and 5.35 and 1.86 times considering homogenization treatments (Fig. 3b). The differences found could be related to the different cell wall structure of different strains.

Overall, it was deduced that glass bead cell disruption method could be an alternative to lysozyme treatment where economics of the process was a concern. In long run for a continuous process in large scales, generally enzyme treatments (e.g., lysozyme) are more expensive compared to physical treatments (e.g., glass bead cell disruption). Initially the capital cost of the devices might be high but will eventually be economically feasible considering that the operational costs are low. Geciova et al. (2002) also determined in a study that glass bead treatment was more effective than homogenization treatment in extracting galactosidase from Streptococcus thermophilus, whereas Bury et al. (2001) determined that they were equally effective. In this context our results confirmed the findings of Geciova et al. (2002). Of course one should not overlook that many parameters such as $\mathrm{pH}$, temperature, age of the culture, shape of cells, structure of the cell wall, and cultivation medium play a significant role on the disruption characteristics of each method and that comparisons should be made under similar conditions (Geciova et al., 2002). Most of the literature is focused on the comparison of various mechanical and chemical cell disruption methods but not on enzymatic. Similarly, the focus is given mainly to Lactobacillus strains but rarely to Streptococcus thermophilus, which also have high potential for $\beta$-galactosidase production. The $\beta$-galactosidase produced by Streptococcus thermophilus is mostly used intracellularly by using the permeablized organism itself for lactose hydrolysis and not the extracted enzyme (Somkuti and Steinberg, 1994). Although this could be economically feasible in many processes, it would not be applicable where only the enzyme and not the whole strain is the preference.

\section{CONCLUSIONS}

In this particular study, the potential of new artisanal strains for lactic acid and $\beta$-galactosidase production were investigated. Strain Lb 77 and strains St 95/2 and St 77a showed high potential for $\beta$-galactosidase activity under static conditions when cultivated in skim milk and M2 growth media, respectively. Furthermore, strain St 95/2 resulted in high lactic acid production. Since $\beta$ galactosidase is an intracellular enzyme, effectiveness of different extraction methods were investigated. Among the methods, lysozyme treatment was determined to be the most efficient extraction method followed by glass bead 
treatment. Finally, strains St 95/2 and Lb 77 were most promising for future studies as potential lactic acid and $\beta$-galactosidase producers.

\section{ACKNOWLEDGMENTS}

The financial support of Turkish Technical and Scientific Council (TUBİTAKTOVAK 104O270) and State Plan Organization (DPT-2005 K 120570) are gratefully acknowledged.

\section{REFERENCES}

Aeschlimann, A., von Stockar, U. (1989). The production of lactic acid from whey permeate by Lactobacillus helveticus. Biotechnol. Lett. 11:195-200.

Altıok, D., Tokatli, F., Harsa, S. (2006). Kinetic modeling of lactic acid production from whey by Lactobacillus caseii (NRRL B-441). J. Chem. Technol. Biotechnol. 81:1190-1197.

Becerra, M., Rodriguez-Belmonte, E., Cerdan, M.E., Siso Gonzales, M.I. (2001). Extraction of intracellular proteins from Kluyveromyces lactis. Food Technol. Biotechnol. 39:135-139.

Beshkova, B.M., Simova, E.D., Frengova, G.I., Simov, Z.I., Spasov, Z.N. (2002). Effect of oxygen on batch yogurt cultures. World J. Microbiol. Biotechnol.18:361-365.

Bulut, C., Gunes, H., Okuklu, B., Harsa, S., Kilic, S., Coban, H.S., Yenidunya, A.F. (2005). Homofermentative lactic acid bacteria of traditional cheese 'Comlek peyniri' from Cappodocia region. J. Dairy Res. 72:19-24.

Bury, D., Hajsmanova, M., Jelen, P. (1999). Growth of Lactobacillus delbrueckii subsp. bulgaricus 11842 whey supplemented with various whey protein concentrates. Milchwiss. 54:610-612.

Bury, D., Jelen, P., Kalab, M. (2001). Disruption of Lactobacillus delbrueckii ssp. bulgaricus 11842 cells for lactose hydrolysis in dairy products: a comparison of sonication, high-pressure homogenization and bead milling. Innov. Food Sci. Technol. 2:23-29.

Büyükkileci, A.O., Harsa, S. (2004). Batch production of L(+) lactic acid from whey by Lactobacillus caseii (NRRL-B 441). J. Chem. Technol. Biotechnol. 79:1036-1040.

Cortes, G., Trujillo-Roldan, M.A., Ramirez, O.T., Galindo, E. (2005). Production of $\beta$-galactosidase by Kluyveromyces marxianus under oscillating dissolved oxygen tension. Process Biochem. 40:773-778.

Datta, R., Henry, M. (2006). Lactic acid: recent advances in products processes and technologies- a review. J. Chem. Technol. Biotechnol. 81:1119-1129.

El Demerdash, H.A., Oxman, J., Heller, K.J., Geis, A. (2006). Yoghurt fermentation at elevated temperatures by strains of Streptococcus thermophilus expressing a small heat-shock protein: application of a two-plasmid system for constructing food grade strains of Streptococcus thermophilus. Biotechnol J. 1:398-404.

Erkuş, O., Celik, E.S., Yavuzdurmaz, H., Okuklu, B., Harsa, S. (2006). Isolation and molecular characterization of artisanal yoghurt starter bacteria. The 20th International ICFMH Symposium on Food Safety and Food Biotechnology: "Diversity and Global Impact”, Bologna, Italy. 
Gaudreau, H., Champagne, C.P., Jelen, P. (2005). The use of crude cellular extracts of Lactobacillus delbrueckii ssp. bulgaricus 11842 to stimulate growth of a probiotic Lactobacillus rhamnosus culture in milk. Enzyme Microb. Technol. 36:83-90.

Geciova, J., Giesova, M., Jelen, P., Plockova, M. (2002). Disruption of Streptococcus thermophilus 143 culture by three mechanical methods for increased $\beta$-galactosidase activity. Milchwiss. 57:509-511.

Ghaly, A.E., Tango, M.S.A., Mahmoud, N.S., Avery, A.C. (2004). Batch propagation of Lactobacillus helveticus for production of lactic acid from lactose concentrated cheese whey with micro aeration and nutrient supplementation. W. J. Microbiol. Biotechnol. 20:65-75.

Greenberg, N.A., Mahoney, R.R. (1982). Production and characterization of $\beta$-galactosidase from Streptococcus thermophilus. J. Food Sci. 47:1824-1828.

Hsu, C.A., Yu, R.C., Chou, C.C. (2005). Production of beta galactosidase by Bifidobacteria as influenced by various culture conditions. I. J. Food Microbiol. 104:197-206.

Jurado, E., Camacho, F., Luzon, G., Vicaria, J.M. (2002). A new kinetic model proposed for enzymatic hydrolysis of lactose by $\beta$-galactosidase from Kluyveromyces fragilis. Enzyme Microb. Technol. 31:300-309.

Kim, J.W., Rajagopal, S.N. (2000). Isolation and characterization of $\beta$-galactosidase from Lactobacillus crispatus. Folia Microbiol. 45:29-34.

Kristo, E., Biliaderis, C.G., Tzanetakis, N. (2003). Modeling of the acidification process and rheological properties of milk fermented with a yogurt starter culture using response surface methodology. Food Chem. 83:437-446.

Mahoney, R.R. (1998). Galactosyl-oligasaccharide formation during lactose hydrolysis: a review. Food Chem.63:147-154.

Martins, D.B.G., de Souza, C.G., Simoes, D.A., de Morais, M.A. (2002). The $\beta$-galactosidase activity in Kluyveromyces marxianus CBS6556 decrease by high concentrations of galactose. Curr. Microbiol.44:379-382.

Mora, B., Fortina, M., Nirastroi, G., Darini, C., Manachini, P.L. (1998). Genotypic characterization of thermophilic bacilli: a study on new soil isolates and several reference strains. Res. Microbiol. 149:711-722.

Nagy, Z., Kiss, T., Szentirmai, A., Biro, S. (2001). $\beta$-galactosidase of Penicillium chrysogenum: production purification and characterization of the enzyme. Protein Exp. Pur.21:24-29.

Nancip, N., Ghoul, M., Larous, L., Nancib, A., Adimi, L., Remmal, M., Boudrant, J. (1999). Use of date products in production of the thermophilic dairy starter strain Streptococcus thermophilus. Bioresource Technol. 67:291-295.

National Academy of Sciences. (1996). Food Chemicals Codex (4th ed.). Washington, DC: National Academy Press, pp. 802-803.

Roe, S. (2001). Protein Purification Techniques: A Practical Approach. Bradford Dyebinding Assay.Oxford: Oxford University Press, p. 31.

Seyis, I., Aksoz, N. (2004). Production of lactase by Trichoderma sp. Food Technol. Biotechnol.42:121-124.

Somkuti, G.A., Steinberg, D.H. (1994). Permeabilization of Streptococcus thermophilus and the expression of beta-galactosidase. Enzyme Microb. Technol. 16:573-576.

Somkuti, G.A., Dominiecki, M.E., Steinberg, D.H. (1996). Sensitivity of Streptococcus thermophilus to chemical permeabilization. Curr. Microbiol. 32:101-105. 
94 C. Tari et al.

Somkuti, G.A., Dominiecki, M.E., Steinberg, D.H. (1998). Permeabilization of Streptococcus thermophilus and Lactobacillus delbureckii subsp. bulgaricus with ethanol. Curr. Microbiol. 36:202-206.

Vasiljevic, T., Jelen, P. (2001). Production of $\beta$-galactosidase for lactose hydrolysis in milk and dairy products using thermophilic lactic acid bacteria. Innov. Food Sci. Emerg. Technol. 2:75-285.

Yokota, T., Sakamoto, H., Takahashi, N. (1989). Beverages by lactic acid fermentation and methods of producing same- United States Patent 4855147. EP Patentfreepatentsonline.com 